\title{
IMPROVEMENT CONSTRUCTED WETLAND PERFORMANCE FOR REDUCING CONTAMINATION LEVELS IN BAHR EL- BAQAR DRAIN, NORTH EAST OF EGYPT
}

\author{
M. S. El-Komy ${ }^{1}$ M. Y. El-Ansary ${ }^{2}$ H. H. Abbas $^{3}$ \\ M.A. Awad ${ }^{4}$ and E.A.Khalifa ${ }^{5}$
}

\begin{abstract}
Nowadays, drainage water is being reused to overcome the gap between the amounts of available and water required. Constructed wetlands, whether of free surface flow or subsurface flow, aim among several purposes, at improving the quality of wastewater. However, the recommended discharge of these wetlands which is $2500 \mathrm{~m}^{3} /$ day, although could decrease the levels of pollutants in wastewater, yet it might be of interest to increase this discharge to meet the increased demands for water. Also, since the efficiency of the wetland to remove pollutants is dependent, among other factors, on the type of the plant cultivated in the surface flow cells, then trying some different types of plants might be fruitful. Therefore, the current study conducted aims at: (1) Assessing the efficiency of the constructed wetland under lower (1250 $\mathrm{m}^{3} /$ day) and higher $\left(5000 \mathrm{~m}^{3} /\right.$ day) discharges than the usual $(2500$ $\mathrm{m}^{3} /$ day). (2)Investigating the use of cattail and papyrus plants in the surface flow cell, compared with the commonly used reed plant..
\end{abstract}

KW: FWS, Free Water Surface, SFW, Sub- Surface Flow Wetland

\section{INTRODUCTION}

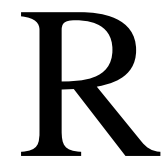
euse of agricultural drainage water is already practiced on a large scale in several countries. In Egypt, due to scarcity of a total of 5.5 Billion Cubic Meters (BCM) of drainage water is being reused after mixing with fresh water. This amount is expected to increase up to 9.6 BCM by the year 2017 (NAWQAM, 1999). Drainage water is actually a combination of agricultural drainage water, industrial effluents, and sewage water with different ratios.

1. Assist. Res. in Drain. Res. Inst. (NWRC), 2, 4 Resp. Prof. Emt. and Assoc. Prof., Ag. Eng. Dept.,3 Head of Soil Dept. Fac. Ag., Benha U., and 5 Prof. Nat. Water Res. C. (NWRC). 
The Egyptian agricultural drains receive discharges of untreated or poorly treated domestic wastewaters, in addition to agricultural drainage water. Therefore, they contain high concentrations of various pollutants such as organic matter, suspended solids, heavy metals and fecal bacteria. Uncontrolled discharge of untreated wastewater to agricultural drains and water resources is a major problem facing the rural areas of Egypt. A major concern when considering drainage water reuse is whether the drainage water quality is within the allowable limits for different uses as outlined by water quality standards and laws or not.

The wetland has water table at or near, or above the land surface or which is saturated for a long enough period to promote wetland or aquatic processes as indicated by hydric soils, and various kinds of biological activity which are adapted to the wet environment. (Mitsch and Gosselink, 2000).

Wetlands are engineered and constructed for four principal reasons as indicated by specific descriptive terminology:

(1) To compensate for and help offset the rate of conservation of natural wetland resulting from agriculture and urban development (constructed habitat wetlands).

(2) To improve water quality (constructed treatment wetlands).

(3) To provide flood control (constructed flood control wetlands).

(4) To be used for production of food and fiber (constructed aquaculture wetlands) (Kaseva, 2004).

Constructed wetlands have been classified into two types. Free water surface (FWS) wetlands (also known as surface flow wetlands) closely resemble natural wetlands in appearance because they contain aquatic plants that are rooted in a soil layer on the bottom of the wetland and water flows among the leaves and stems of plants. Subsurface flow (SFS) wetlands systems (also known as vegetated submerged bed (VSB)) which do not resemble natural wetlands because they have no standing water. They contain a bed of media (such as crushed rock, small stones, gravel, sand or soil) which have been planted with aquatic plants (EPA, 2000).

\section{The main objectives of this paper are:}

1. Assessing feasibility of constructed wetland system to improve the water quality so that it becomes suitable for different uses. 
2. Decreasing time of treating the discharged water

3. Decreasing the level of pollutants flowing into Lake Manzala (بحيرة (المنزلة) and the Mediterranean Sea.

4. Increasing quantity of the treated discharged water.

\section{Materials And Methods}

The study area is located at the southern edge of Lake Manzala as shown in figure (1). According to sedimentomorphic soil maps (MacLaren, 1982) and the soil study of Lake Manzala by the Japanese International Cooperation Agency (JICA), Bahr El- Baqar drainage (مصرف بحر البقر) water constructed wetland is located in the Coastal Plain and the soil type is Fluviomarine Deposits. These types of soils are covered by a thin, fluffy layer of clay, and often a thin salt crust is found on the surface. The groundwater table ranges from 0.5 to $1.5 \mathrm{~m}$ below the soil surface. The annual rainfall is approximately $67 \mathrm{~mm}$. The highest absolute recorded temperature is $46 \mathrm{C}^{\circ}$, occurring in June, while the lowest temperature of $0 \mathrm{C}^{\circ}$ is recorded in February. The average annual temperature in the area is $28 \mathrm{C}^{\circ}$.

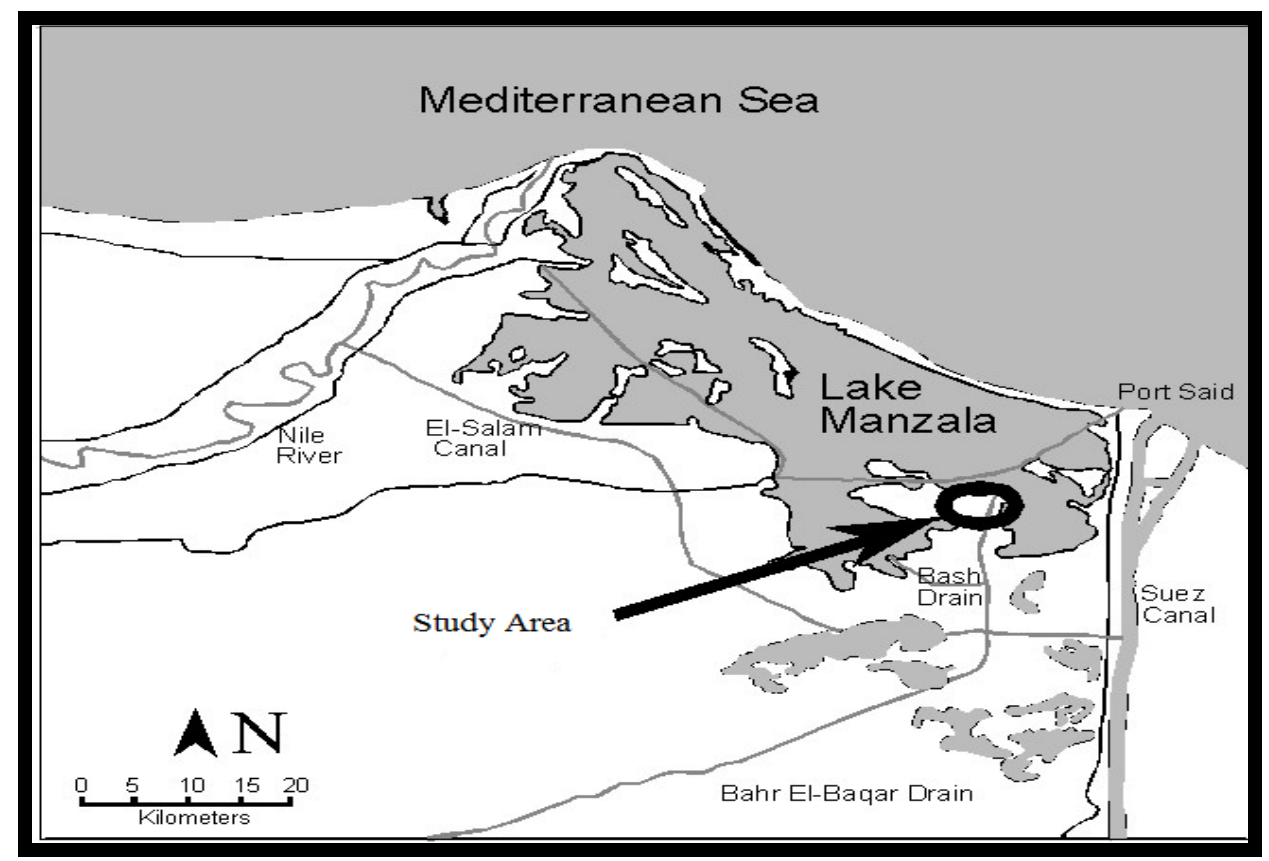

Figure (1) Bahr El-Baqar drain water constructed wetland (study area site), 


\section{2a.Characteristics Of Bahr El-Baqar drain}

Bahr EI-Baqar drain is the largest and most polluted drain of the seven drains discharging into Lake Manzala (5.5*10 $\mathrm{m}^{3} /$ year), (DRI, 2000). The drain originates at Cairo collecting agricultural, industrial and sewage water for three oilier governorates before reaching Lake Manzala with a total length of more than $200 \mathrm{~km}$ (Fig.1). Wastewater in the drain is composed of particulate heavy metal, hydrocarbons and residues of toxic compounds such as herbicides and pesticides (TVA, 1999). Despite the fact that Bahr El Baqar is the largest drain in the Eastern Delta, it was excluded from supplying El-Salam Canal, delivering mixed drainage and fresh water to Sinai due to its high level of pollution. This condition results in loss of large amounts of water that could have been reused for irrigation.

The drain water quantity and quality is dynamic in response to the fluctuation in the water uses and discharge of fresh water in the drain in years of high floods (Table 1). A general characteristic of the drain was the prevailing of anaerobic conditions and absence of dissolved oxygen in the last reaches of the drain (DRI, 2000). Dissolved oxygen in the drain started to be observed after the operation of Cairo wastewater treatment project (Gabal Al Asfar الجبل الأصفر). Meanwhile, discharge from reclaimed lands in the vicinity of the drain has added more agricultural drainage water to the drain which is reflected in higher salinity levels. Table (1) shows the observed variation in water quality for years 1999 to 2003.

Table (1) Water quality of Bahr EI-Baqar Drain for the years (1999-2003), (source: DRI, 2005)

\begin{tabular}{|l|c|c|c|c|c|}
\hline Parameter & $\mathbf{1 9 9 9}$ & $\mathbf{2 0 0 0}$ & $\mathbf{2 0 0 1}$ & $\mathbf{2 0 0 2}$ & $\mathbf{2 0 0 3}$ \\
\hline TSS(mg/L) & 147.1 & 237.1 & 85 & 92 & 65.6 \\
\hline BOD(mg/L) & 39.3 & 60.3 & 66 & 58 & 53.5 \\
\hline Chloride (mg/L) & 26.1 & 35.7 & 38.2 & 29.4 & 35.7 \\
\hline pH & 7.7 & 7.8 & 7.88 & 7.6 & 7.3 \\
\hline EC (dS/m) & 4.3 & 5.8 & 5.2 & 5.1 & 5.8 \\
\hline $\begin{array}{l}\text { Dissolved Oxygen } \\
\text { (mg/L) }\end{array}$ & 2 & 1.8 & 1.65 & 1.85 & 2 \\
\hline Ammonia (mg/L) & 3.9 & 5.2 & 4.3 & 3.65 & 4.2 \\
\hline Total N (mg/L) & 9.1 & 12.06 & 18.6 & 12.2 & 14.95 \\
\hline Total P (mg/L) & 1.42 & 0.98 & 1.22 & 1.32 & 1.17 \\
\hline $\begin{array}{l}\text { F. Coliform } \\
\text { (CFU/100mL) }\end{array}$ & $3.9 * 10^{5}$ & $2 * 10^{4}$ & $6 * 10^{4}$ & $8 * 10^{4}$ & $3 * 10^{3}$ \\
\hline
\end{tabular}

DRI: Drainage Research Institute. 


\section{2b.Components of Bahr El-Baqar Constructed Wetland (BCW)}

BCW contains: intake structure, pump station, sedimentation basin, 10 free water surface wetland cells, reciprocating cells (two subsurface flow wetland cells), fishery facility and fish farm as shown in Figure (2).

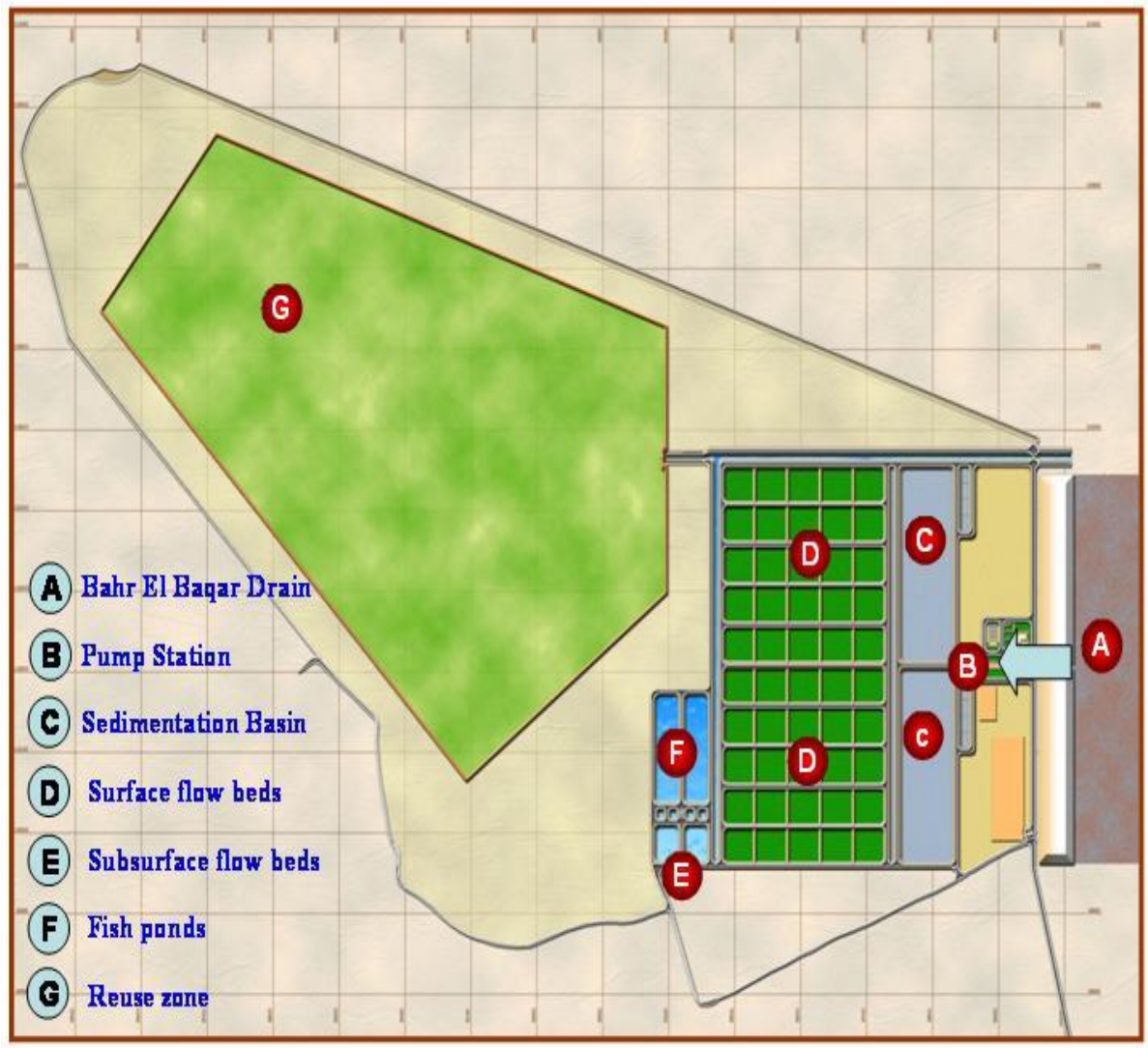

Figure (2) Major Components of (BCW)

\section{2c.Water Intake and Pumping Station}

The total study area is about 240 feddan and the total wetland system area is about 80 feddans. The intake channel selectively withdraws water from the upper half of Bahr El Baqar drain (A). Two course bar screens and a floating baffle prevent larger materials from entering the treatment system. Two 12,500 cubic meter per day $\left(522 \mathrm{~m}^{3} / \mathrm{h}\right)$ screw pumps lift the intake water approximately 3 meters into the sediment basins and provide hydraulic gradient for gravity flow through the remainder of the system. The station is operated by means of two diesel generators (B). 


\section{2d.Sediment Basins}

Two sedimentation basins (C) of approximately $250 * 90 \mathrm{~m}$ and $1.5 \mathrm{~m}$ depth are provided with gravel media for the receiving of sediments accumulated in the sedimentation ponds with time and provide primary treatment. Sludge is periodically removed to conventional drying beds and disposed in accordance with environmental regulations. A majority of the metals will be removed by this part of the treatment process.

Flow is equally distributed between the two ponds as shown in Table (3).

Table (2) Design parameters for sedimentation basin

\begin{tabular}{|l|l|l|}
\hline Parameter & Units & Value \\
\hline Average flow rate & $\mathrm{m}^{3} / \mathrm{d}$ & 12500 \\
\hline Detention time & Days & 2 \\
\hline Total depth & $\mathrm{m}$ & 2.5 \\
\hline Operating depth & $\mathrm{M}$ & 1.5 \\
\hline Volume of water & $\mathrm{m}^{3}$. & 25000 \\
\hline Area & $\mathrm{m}^{2}$. & 22500 \\
\hline Length & $\mathrm{M}$ & 250 \\
\hline Width & $\mathrm{M}$ & 90 \\
\hline Side slope & non & $3: 1$ \\
\hline Bottom Slope & $\%$ & 0 \\
\hline
\end{tabular}

\section{2e.Surface Flow Treatment Cells}

Effluent from the sedimentation basins flows to ten surface flow cells through distribution canal (D). Each cell is divided into five compartments by open water trenches designed to redistribute lateral flow and reduce short circuiting. In order to test removal efficiencies at different flow rates, three low flow cells (approximately 1250 cubic meters per day)), medium flow cells (approximately 2500 cubic meters per day), have loading rate similar to conventional wetland systems), and high flow (approximately 5000 cubic meters per day) .

The cells were planted with common reed, cattail and papyrus emergent plants. Each treatment was replicated three times as shown in Table (3).

Planting started at a density of four plants (rhizomes) per square meter and was transplanted manually. After one year, plant density was increased to 20 plants (rhizomes) per square meter.

The parameters characterizing each cell are listed in table (4). Flow of water was controlled in the surface flow (SFW) cells at inlet and outlet with control valves and measured by Ultra Sonic meters. 
Table (3): Design parameters for low, med., and high flow cells with (Reed - Cattail - Papyrus) plants.

\begin{tabular}{|l|c|c|c|c|}
\hline Parameter & Unit & $\begin{array}{c}\text { Low } \\
\text { flow }\end{array}$ & $\begin{array}{c}\text { Med. } \\
\text { flow }\end{array}$ & $\begin{array}{c}\text { High } \\
\text { flow }\end{array}$ \\
\hline Average flow rate & $\mathrm{m}^{3} / \mathrm{d}$ & 1250 & 2500 & 5000 \\
\hline Detention time & Days & 4 & 2 & 1 \\
\hline Hydraulic loading rate & $\mathrm{m} / \mathrm{day}$ & 0.1 & 0.2 & 0.4 \\
\hline Operating depth & $\mathrm{m}$ & 0.4 & 0.4 & 0.4 \\
\hline
\end{tabular}

\section{2. f. Reciprocating Subsurface Flow Treatment Cells}

In this system the cells have a design capacity of 500 cubic meters per day and will initially treat effluent from the sediment basins. Alternatively, effluent from the surface flow cells can be used to supply the reciprocating cells. Two pumps $47 \mathrm{l} / \mathrm{s}$ each with $3 \mathrm{~m}$ head operating at $1500 \mathrm{rpm}$ are used to reciprocate water between the two cells. The cells are filled with graded gravel and produce an effluent water suitable for supplying inflow to the fish-rearing facility.

\section{2g. Design Criteria}

Table (4) Design inflow characteristics based on available data (P. Lane 1992b; 1993a; Drain. Res. Inst. 1998; 2000).

Table (4): Design Criteria for Influent Water Quality

\begin{tabular}{|l|c|c|}
\hline Parameter & Units & Value \\
\hline Daily flow & $\mathrm{m}^{3}$ & 25,000 \\
Total BOD & $\mathrm{mg} / \mathrm{L}$ & 40 \\
Total COD & $\mathrm{mg} / \mathrm{L}$ & 100 \\
Total suspended solids & $\mathrm{mg} / \mathrm{L}$ & 160 \\
Total phosphorus & $\mathrm{mg} / \mathrm{L}$ & 5 \\
Total nitrogen & $\mathrm{mg} / \mathrm{L}$ & 12 \\
pH & ---- & 7.5 \\
Conductivity & $\mathrm{dS} / \mathrm{m}$ & 4 \\
\hline
\end{tabular}

\section{2h. Performance Calculation of Surface Flow Cells}

The hydraulic loading rate is defined as

$$
q=\left(\frac{Q}{A}\right)
$$

where,

$\mathrm{q}=$ Hydraulic loading rate, $\mathrm{m} / \mathrm{d}$

$\mathrm{Q}=$ Water flow, $\mathrm{m}^{3} / \mathrm{d}$

$\mathrm{A} \quad=$ Wetland area, $\mathrm{m}^{2}$ 


\section{2i. Performance Calculation of the Sedimentation Basin}

The main function of the sedimentation basin is to hold and bake suspended sediment, phosphorus and heavy metals adsorbed to the sediment.

The basic formula to calculate the sedimentation in the basin is Stoke's law and the retention time, as follows:

$\mathrm{V}=\left(2 \mathrm{gr}^{2}\right)(\mathbf{d}-\mathrm{D}) / \mathbf{9 u}$,

\section{where,}

$\mathbf{V}=$ velocity

$\mathbf{g}=$ acceleration due to gravity $\left(981 \mathrm{~cm} / \mathrm{sec}^{2}\right)$

$\mathbf{r}=$ radius of particle $(\mathrm{cm})$

$\mathbf{d}=$ density of particle $\left(\mathrm{g} / \mathrm{cm}^{3}\right)$

$\mathbf{D}=$ density of water $\left(1 \mathrm{~g} / \mathrm{cm}^{3}\right)$

$\mathbf{u}=$ dynamic viscosity of water $(\mathrm{g} / \mathrm{cm} /$ day $)$

Retention time is calculated as:

$\mathbf{T}=\mathbf{S} / \mathbf{E}(\mathbf{Q})$

\section{Where,}

$\mathbf{T}=$ retention time $(\mathrm{sec})$

$\mathbf{S}=$ Volume of sedimentation basin $\left(\mathrm{m}^{3}\right)$

$\mathbf{E}(\mathrm{Q})=$ Average discharge $\left(\mathrm{m}^{3} / \mathrm{sec}\right)$

\section{2j. Removal Efficiency}

The amount of pollution removed from receiving water can be quantatively expressed in terms of the removal efficiency (RE), between 0 and 100 percent. RE is defined as:

$$
\mathbf{R E}=\left(\frac{\mathrm{C}_{\mathrm{i}}-\mathbf{C}_{\mathrm{e}}}{\mathbf{C}_{\mathrm{i}}}\right) \mathbf{x 1 0 0}
$$

Where,

$$
\begin{array}{ll}
\mathbf{C}_{\mathbf{i}} & \text { =inflow pollutant concentration } \\
\mathbf{C}_{\mathbf{e}} & \text { = outflow pollutant concentration }
\end{array}
$$

\section{2k. Monitoring and Sampling Locations}

Water sampling was scheduled on a biweekly monitoring. There are two types of measurements for the collected water samples, first field measurements for some parameters such as second lab analysis for the 
water quality. All sampling procedures and analyses were carried out according to EPA standard methods.

Water samples were collected from the designed monitoring locations and delivered to the central environmental laboratories of the National Water Research Center for water quality analysis. These analyses were to determine water quality parameters, including total suspended solids (TSS), biochemical oxygen demand (BOD), total nitrogen (TN), total phosphorus (TP), heavy metals such as; iron (Fe) manganese (Mn), zinc $(\mathbf{Z n})$,lead $(\mathbf{P b})$, copper $(\mathbf{C u})$ and nickel $(\mathbf{N i})$, beside the fecal coliform bacteria (FC) and total coliform bacteria (TC).

\section{3a.Total suspended solids (TSS)}

\section{RESULTS AND DISCUSSION}

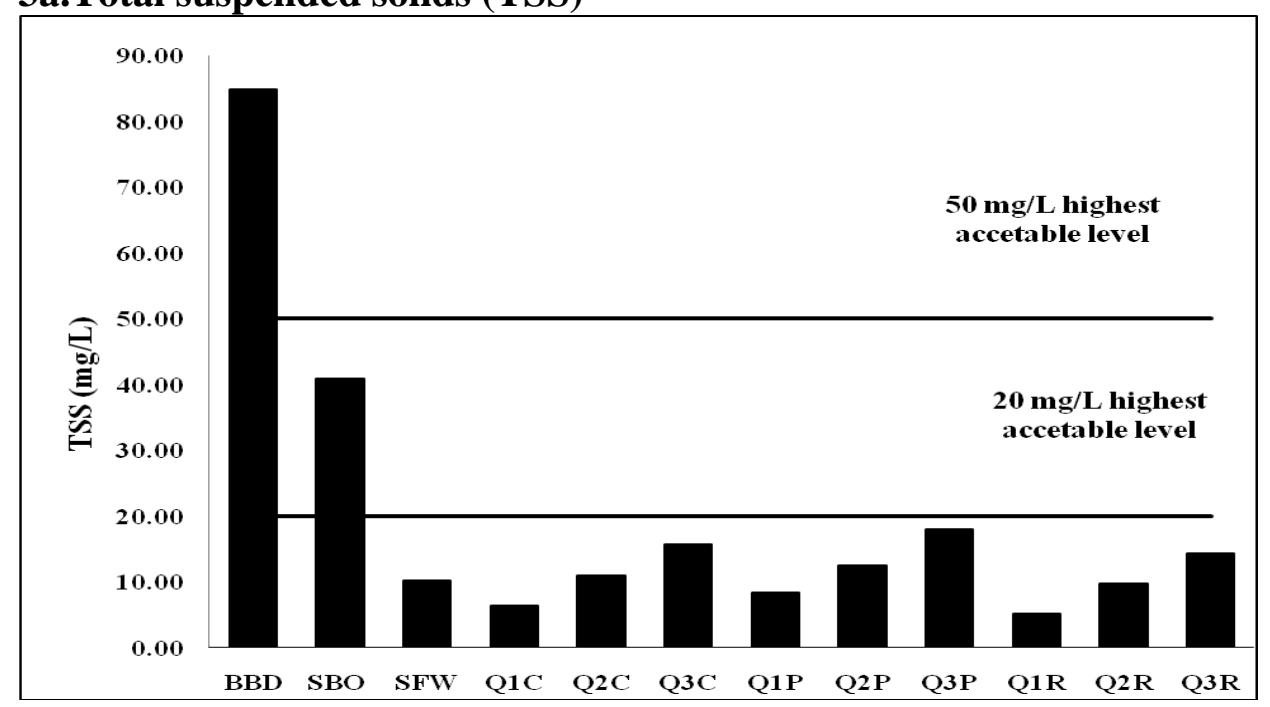

Treatment

BBD Bahr El Baqar Drain. SBO Sedimentation Basin Outlet. SFW Subsurface Free Wetland, Q1C Discharge (1250 $\mathrm{m}^{3} /$ day), Cattail., Q2C Discharge (2500 $\mathrm{m}^{3} /$ day), Cattail., Q3C Discharge (5000 $\mathrm{m}^{3} /$ day), Cattail., Q1P Discharge $\left(1250 \mathrm{~m}^{3} /\right.$ day $)$, Papyrus.,Q2P Discharge (2500 $\mathrm{m}^{3} /$ day), Papyrus., Q3P Discharge (5000 $\mathrm{m}^{3} /$ day), Papyrus., Q1R Discharge (1250 $\mathrm{m}^{3} /$ day), Reed., Q2R Discharge $\left(2500 \mathrm{~m}^{3} / \mathrm{day}\right)$, Reed and Q3R Discharge (5000 $\mathrm{m}^{3} /$ day), Reed.

Fig (3) TSS concentrations under different treatments.

Results in Figure (3) show values of TSS concentration under the different wetland systems, i.e. free water surface (FWS) and the 
subsurface wetland (SFW) as well as the different studied discharges Q1,Q2 and Q3.(i.e. 1250,2500 and $5000 \mathrm{~m} 3$ /day)beside the different cultivated plants $\mathrm{C}, \mathrm{P}$, and $\mathrm{R}$ (i.e. cattail, papyrus and reed ). The maximum values of removal of TSS were attained due to (Q1C andQ1R), , while the corresponding minimum ones were achieved due to $(\mathrm{Q} 3 \mathrm{P}$ and $\mathrm{Q} 3 \mathrm{C}$ ).However, all of these values were under the permissible limits, while those of water of BBD are obviously higher than the permissible ones i.e. $20-50 \mathrm{mg} / \mathrm{L}$ according to NAWQAM (2007). At sedimentation basin outlet (SBO), values of TSS, although were reduced as compared with those of BBD, yet these values remained somewhat higher than the permissible ones.

\section{3b. Biological oxygen demand (BOD)}

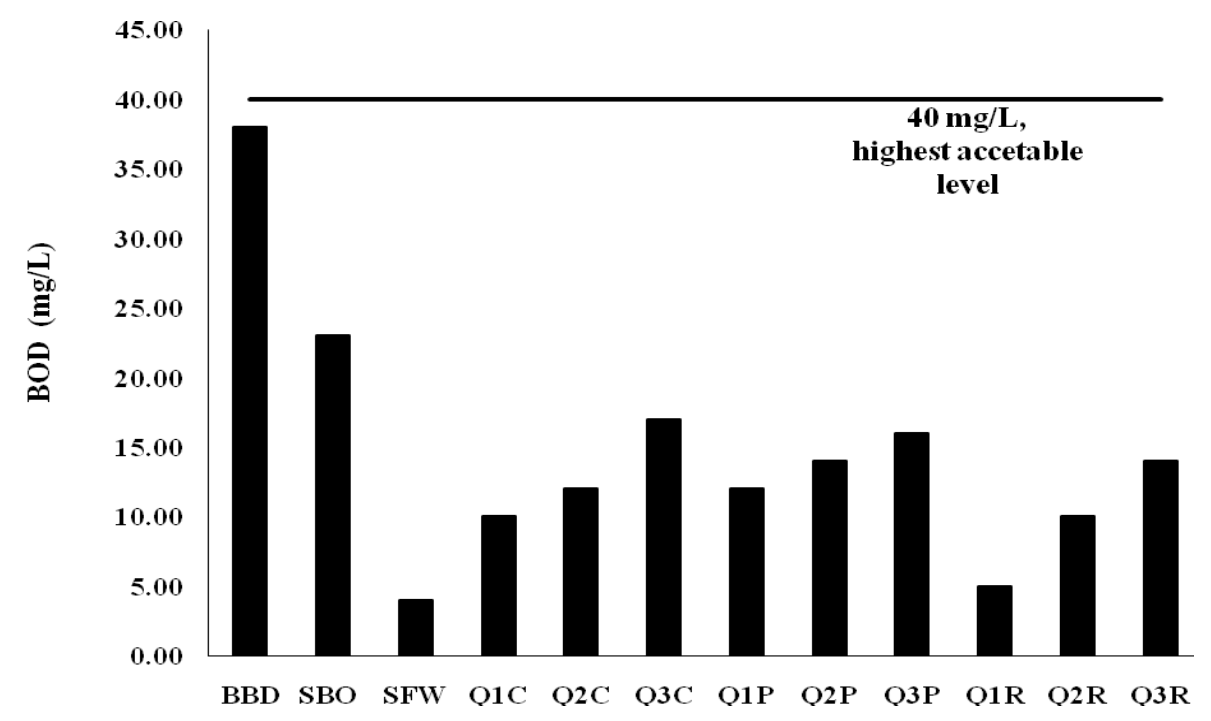

See footnote of Fig. (3)

Treatment

Fig. (4): BOD concentration under different treatments.

Results in Figure (4) show concentrations of BOD under the studied treatments. The maximum removal values of BOD were due to (SFW andQ1R) treatments, On the other hand, the minimum values of BOD removal were achieved due to Q3C, Q3P, Q3R and Q2P treatments 
.However, all of these values were under limit of TSS as reported in NAWQAM 2007. Also, values of BOD of water of BBD were lower than the permissible one i.e. $40 \mathrm{mg} / \mathrm{L}$. Likewise, at the sedimentation basin outlet (SBO), values of BOD seemed to be lower than the permissible one.

\section{3c. Total nitrogen (TN)}

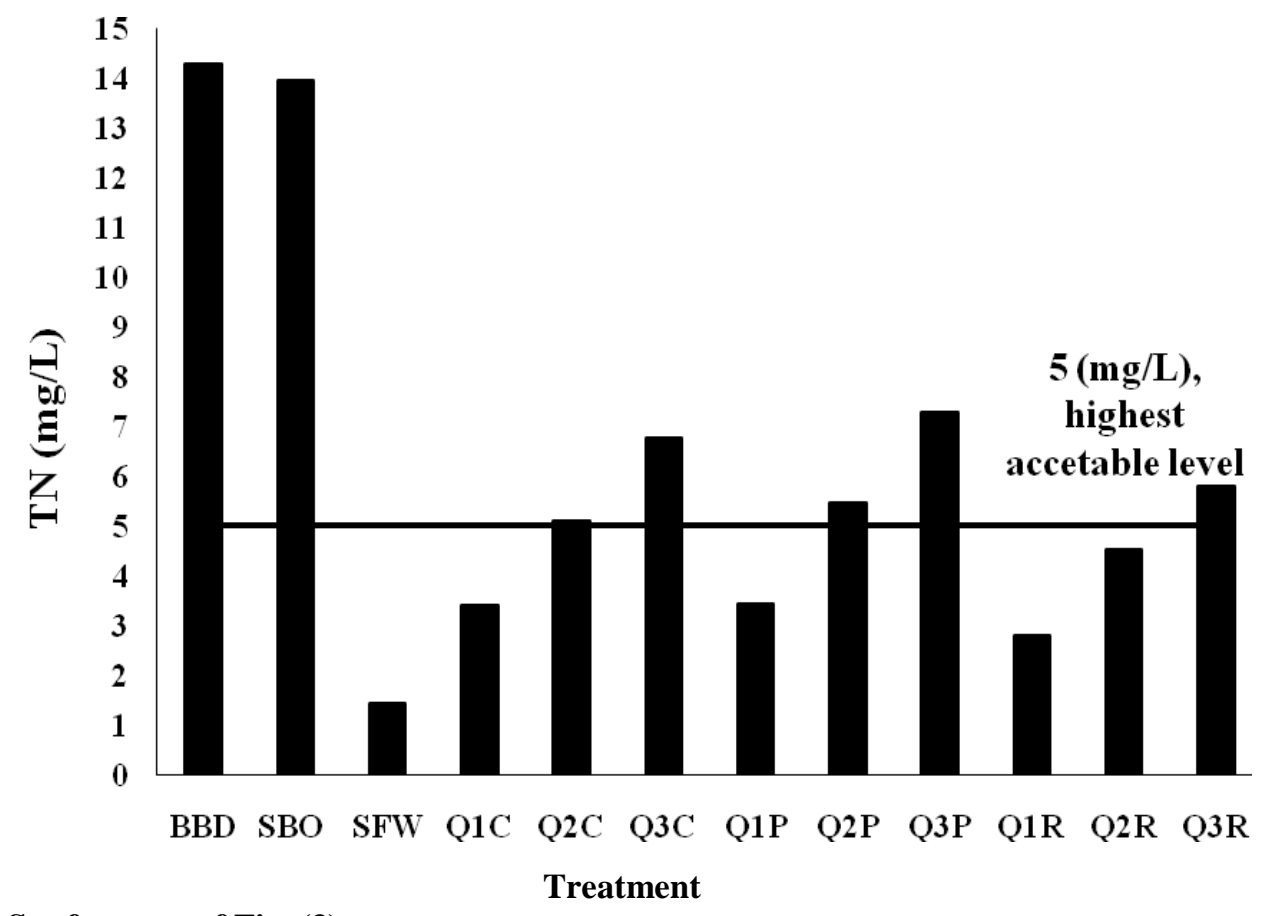

See footnote of Fig. (3)

Fig (5): TN concentration under different treatments.

Figure (5) shows concentration of TN attained under the studied treatments. Removal of TN was highest owing to the treatments (SFW). However, as well as all the concentrations achieved by Q1R, Q1C, Q1P and Q2R treatments, were lower than permissible limit proposed by FAO (1985). On the other hand, the lowest removal of TN occurred due to the treatments, Q3C, Q3P and Q3R where values of $\mathbf{T N}$ achieved due to these treatments as well as those of water of BBD, were obviously higher than the permissible one. At the sedimentation basin outlet (SBO), values 
of $\mathbf{T N}$, although were very slightly lower than those of BBD, yet these values remained somewhat higher than the permissible ones.

\section{3d. Total phosphorus (TP)}

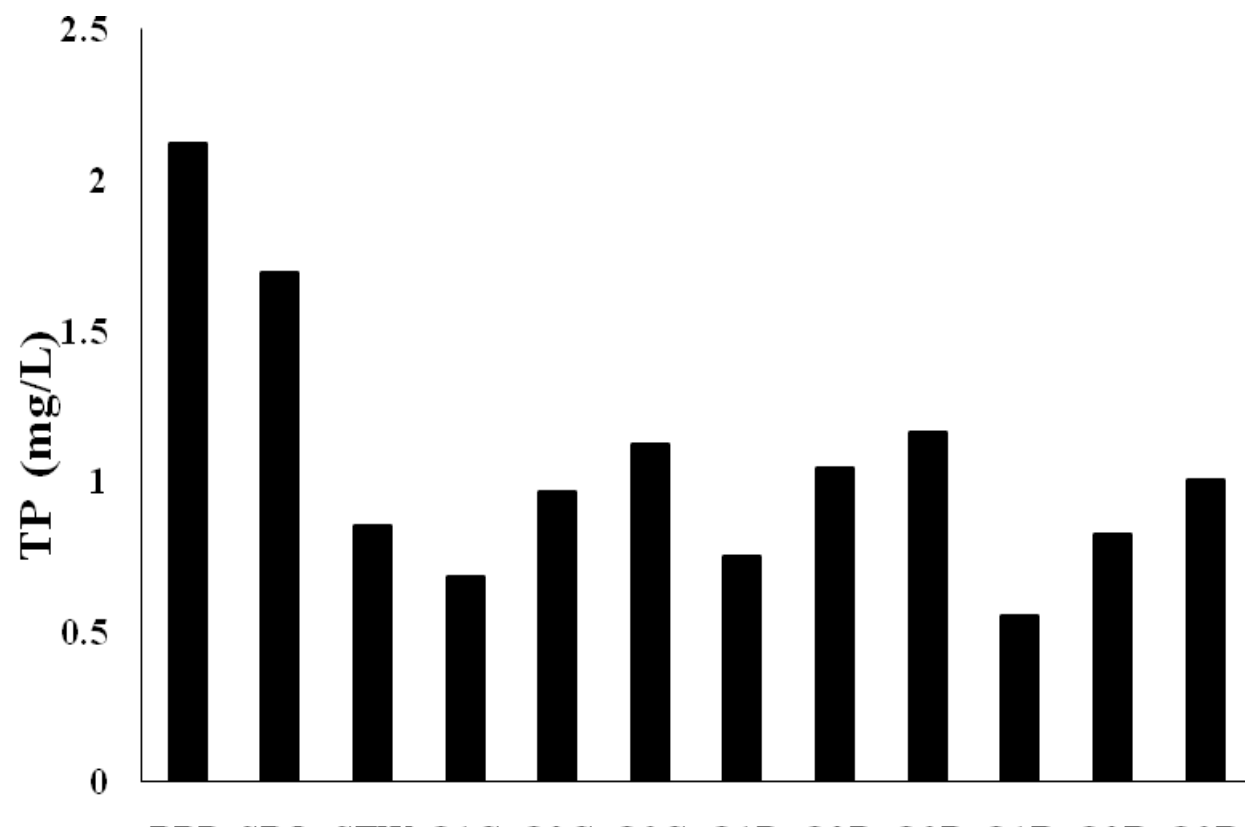

BBD SBO SFW Q1C Q2C Q3C Q1P Q2P Q3P Q1R Q2R Q3R

See footnote of Fig. (3)

Fig (6) TP concentration under different treatments.

Figure (6) shows concentration of TP under the studied treatments. The maximum removal of $\mathbf{T P}$ was attained due to the treatments Q1R while the minimum removal values of $\mathbf{T P}$ were achieved due to the treatments Q2P, Q3P and Q3C.However, all of these values were under permissible limit of TP $9.7 \mathrm{mg} / \mathrm{L}(=30 \mathrm{mg} \mathrm{PO} / \mathrm{L})$ as reported by (FAO, 1992 and National Academy of Science-National Academy of Engineering 1973). TP values of BBD water were higher than those of the wetland treated ones. Also TP of water at sedimentation basin outlet (SBO), were reduced as compared with those of BBD water .However, TP values of all the studied waters i.e. at $\mathrm{BBD}, \mathrm{SBO}$ and the other treatments were obviously lower than TP values reported as highest acceptable limit 
3e. Heavy Metals:

Table (5): Heavy Metals Concentration in mg/L

\begin{tabular}{|c||c||c||c||c||c||c||c||}
\hline \multirow{2}{*}{ Parameter } & \multicolumn{7}{|c|}{ Concentration of heavy metals in mg/L } \\
\cline { 2 - 7 } & $\mathbf{F e}$ & $\mathbf{P b}$ & $\mathbf{Z n}$ & $\mathbf{C u}$ & $\mathbf{M n}$ & $\mathbf{N i}$ & $\mathbf{C d}$ \\
\hline \hline BBD & $\mathbf{0 . 8 9 2}$ & $\mathbf{0 . 0 2 1}$ & $\mathbf{0 . 0 4 6 0}$ & $\mathbf{0 . 0 3 0 4}$ & $\mathbf{0 . 1 6 4}$ & $\mathbf{0 . 0 1 9}$ & $\mathbf{0 . 0 0 4}$ \\
\hline \hline SBO & $\mathbf{0 . 7 8 8}$ & $\mathbf{0 . 0 1 7}$ & $\mathbf{0 . 0 4 6 0}$ & $\mathbf{0 . 0 2 9 8}$ & $\mathbf{0 . 1 4 6}$ & $\mathbf{0 . 0 1 9}$ & $\mathbf{0 . 0 0 4}$ \\
\hline \hline SFW & $\mathbf{0 . 1 5 6}$ & $\mathbf{0 . 0 0 6}$ & $\mathbf{0 . 0 1 1 3}$ & $\mathbf{0 . 0 0 3 9}$ & $\mathbf{0 . 0 4 3}$ & $\mathbf{0 . 0 0 6}$ & $\mathbf{0 . 0 0 0 4}$ \\
\hline \hline Q1C & 0.139 & 0.007 & 0.0107 & 0.0068 & 0.035 & 0.0062 & 0.0005 \\
\hline \hline Q2C & 0.215 & 0.009 & 0.0128 & 0.0104 & 0.044 & 0.0079 & 0.0005 \\
\hline \hline Q3C & 0.26 & 0.009 & 0.0174 & 0.0136 & 0.051 & 0.0088 & 0.0008 \\
\hline \hline Q1P & 0.108 & 0.007 & 0.0089 & 0.0044 & 0.039 & 0.0057 & 0.0005 \\
\hline \hline Q2P & 0.193 & 0.008 & 0.0121 & 0.0076 & 0.052 & 0.0075 & 0.0005 \\
\hline \hline Q3P & 0.253 & 0.009 & 0.0154 & 0.0107 & 0.063 & 0.0085 & 0.0008 \\
\hline \hline Q1R & 0.092 & 0.007 & 0.0073 & 0.0035 & 0.032 & 0.0056 & 0.0005 \\
\hline \hline Q2R & 0.177 & 0.007 & 0.0089 & 0.0056 & 0.04 & 0.0062 & 0.0005 \\
\hline \hline Q3R & 0.216 & 0.008 & 0.0124 & 0.0087 & 0.044 & 0.0068 & 0.0006 \\
\hline \hline
\end{tabular}

See footnote of Fig. (3)

Table (5) heavy metals concentration under different treatments.

Data illustrated in Table (5) reveal that concentrations of the studied heavy elements i.e. $\mathrm{Fe}, \mathrm{Mn}, \mathrm{Zn}, \mathrm{Pb}, \mathrm{Cu}, \mathrm{Ni}$, and $\mathrm{Cd}$ were less than the corresponding permissible limits i.e. 5, 0.2, 5, 5, 0.2, 0.2 and $0.2 \mathrm{mg} / \mathrm{L}$ as reported by (FAO, 1992 and National Academy of Science-National Academy of Engineering, 1973). This was true even for the BBD water and the water of the sedimentation basin outlet. However, the secondary treatments contributed to more reduction in concentrations of these heavy metals.

Table (5) show concentrations of $\mathrm{Fe}, \mathrm{Mn}, \mathrm{Zn}, \mathrm{Pb}, \mathrm{Cu}, \mathrm{Ni}$, and $\mathrm{Cd}$ under the different wetland systems i.e. free water surface (FWS) at the different studied discharges i.e. 1250,2500 and $5000 \mathrm{~m}^{3} /$ day beside the different cultivated plants i.e. cattail, papyrus and reed plant. The maximum values of removal were attained due to the treatments Q1R, for $\mathrm{Fe}, \mathrm{Mn}, \mathrm{Zn}, \mathrm{Pb}, \mathrm{Cu}, \mathrm{Ni}$, and $\mathrm{Cd}$, while the minimum ones were 
achieved due to the treatments $\mathrm{Q} 3 \mathrm{C}$. For, $\mathrm{Zn}, \mathrm{Pb}, \mathrm{Cu}, \mathrm{Ni}$, and $\mathrm{Cd}$ while the minimum value of removal of the $\mathrm{Mn}$ was attained due to the treatment Q3P.

\section{3f. Total Coliform (TC)}

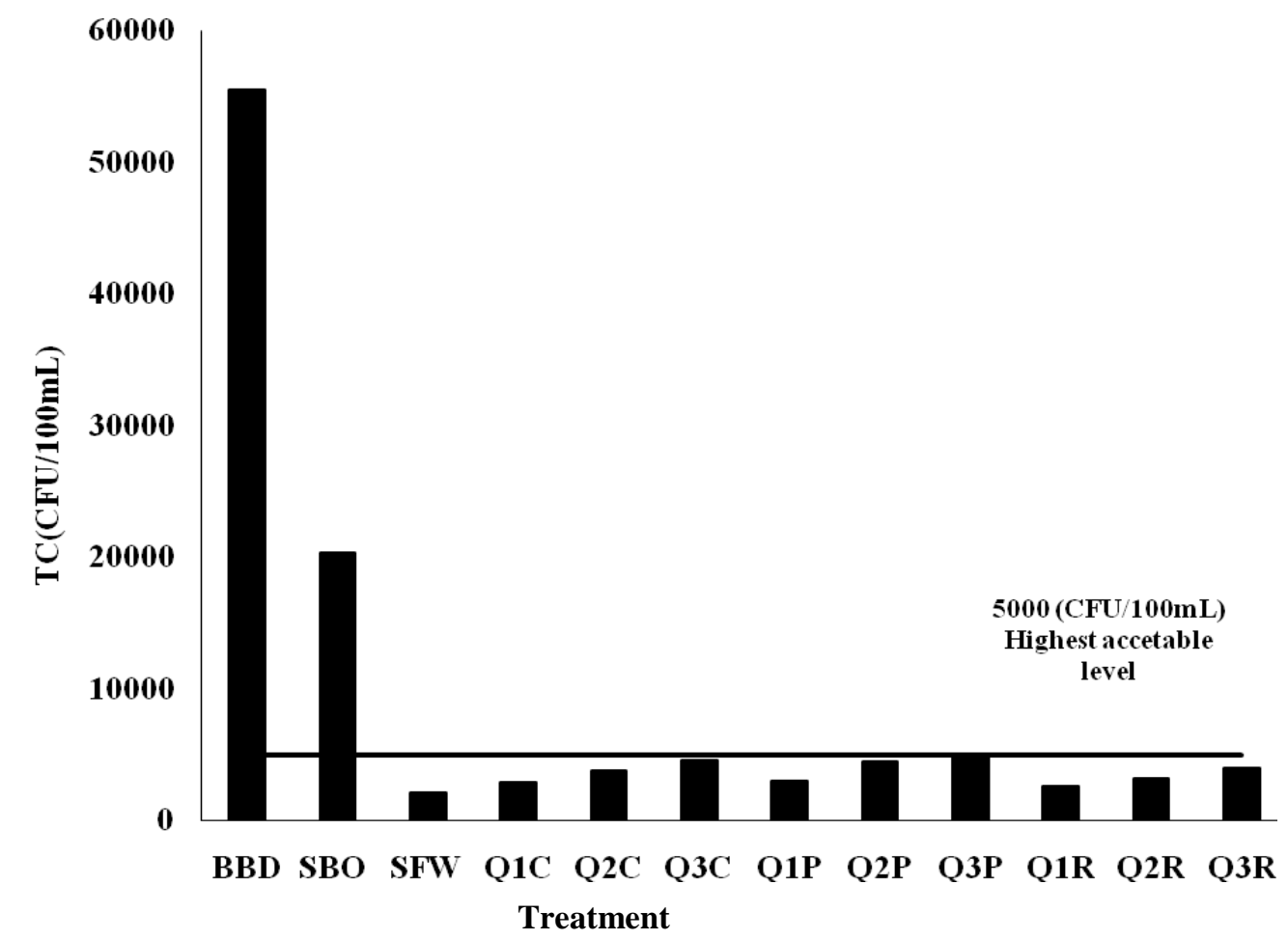

See footnote of Fig. (3)

Fig (14) TC concentration under different treatments.

Fig. (14) reveals that the sedimentation basin could reduce values of TC at BBD water effectively. However, those values remained far higher than the permissible limit which is $5000 \mathrm{CFU} / 100 \mathrm{~mL}$. (FAO, 1992 and National Academy of Science-National Academy of Engineering , 1973).

The different wetland systems regardless of the water discharge and type of the cultivated plant could reduce concentrations of TC to values less than the above mentioned highest permissible level. 


\section{3g. Fecal Coliform (FC)}

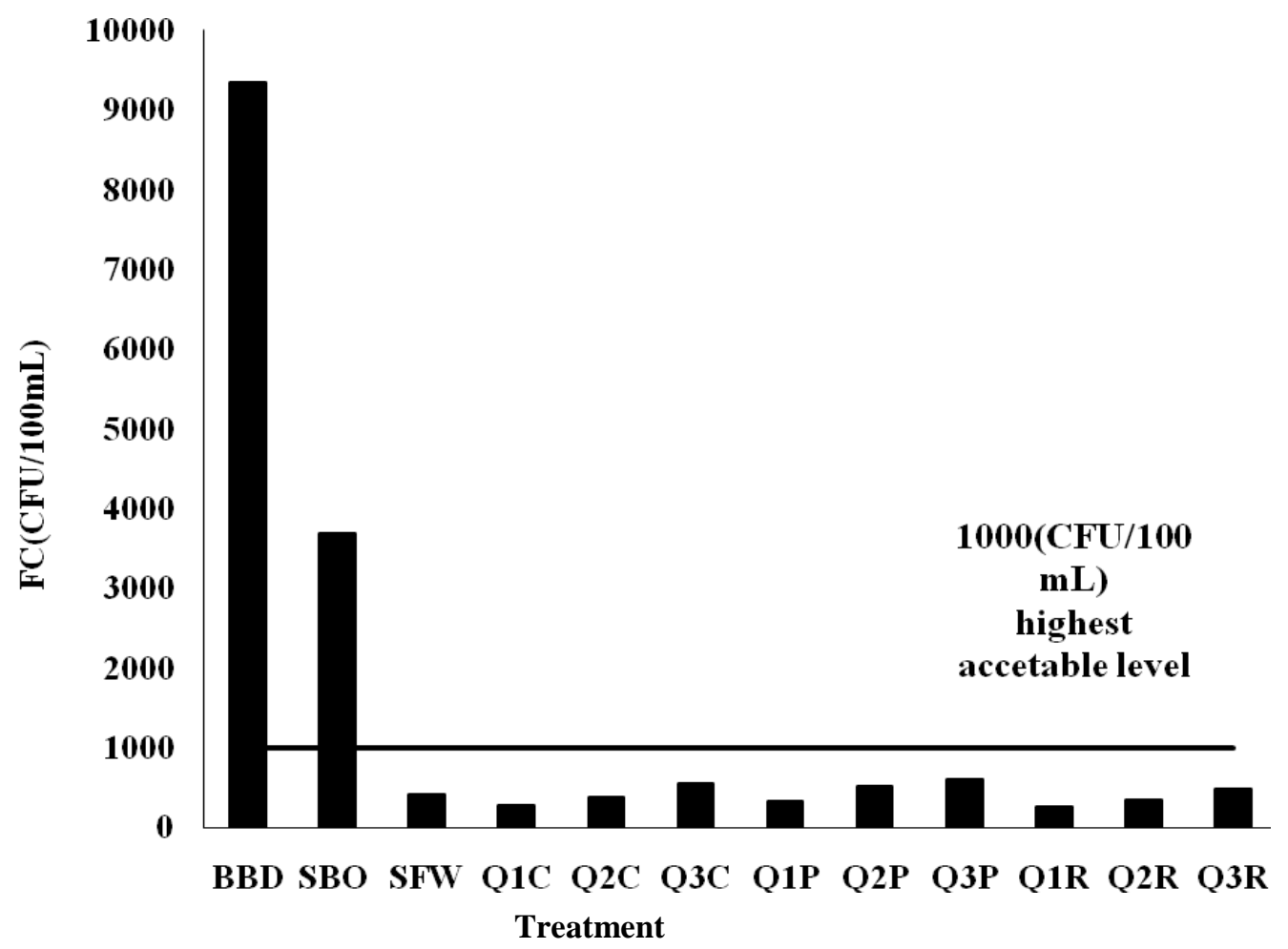

See footnote of Fig. (3)

Fig (15): FC concentration under different treatment systems.

Fig.(15) illustrates that count of FC of BBD water exceeded highly the highest permissible count of FC in water to be used for irrigation which is $1000 \mathrm{CUF} / 100 \mathrm{~mL}$ according to NAWQAM (2007). The sedimentation basin could reduce this count but to levels still higher than the permissible one . Regardless of the wetland system or the water discharge and type of the cultivated plant, all the studied treatments succeeded to reduce count of the FC to less the $1000 \mathrm{CFU} / 100 \mathrm{~mL}$. However, very few differences could be observed among the different treatments.

\section{CONCOLUSION}

The results showed that the highest removal efficiencies for TSS were achieved owing to the treatment Q1R, however, all the other treatments could reduce level of TSS to less than the acceptable one. BOD was 
reduced and the effects seemed to be highest with the SFW and Q1R treatments. The treatments SFW and Q1R showed also the highest removal values of $\mathrm{TN}$ and $\mathrm{TP}$, respectively.

However, it is worthy to indicate that the initial concentration of TP at the intake of BBD water was lower than the permissible level. Also, the heavy metals contents at the intake of BBD were less than the permissible ones. However, all the treatments could reduce these metal concentrations to lower values.

Regardless of the wetland system, water discharge or cultivated plant, all the treatments were efficient in reducing the count of FC to values less than highest permissible level.

Finally it can be concluded that using either of the studied discharge is dependent on the required levels of the pollutants present in the treated wastewater, which means it would be preferred to use the lowest discharge if the required concentration of a contaminant is low. On the other hand, the highest discharge would be preferable if high amounts of wastewater are available, and at the same time, this discharge provides concentrations of the different pollutants below the highest permissible ones.

Regarding to the different studied plants, it was proved that the reed plant showed the highest removal efficiency of all the pollutants.

\section{REFERENCES}

DRI, Drainage Research Institute (2000), "A Water Quality Survey for Bahr El Baqar Drain September 1999 - February 2000" ARE, Min. Publ. Works and Water Resources: pp 50-90

DRI, Drainage Research Institute (2003), Field Metrological Data of Weather Station at South El Hessanya Plain, El Salam Canal, Unpubl. Data.

DRI, Drainage Research Institute (2005), Third technical report for the integrated water quality and quantity (Jan2005-Dec2005): pp 12-50

EPA.U.S. Environmental Protection Agency (2000). "Constructed Wetlands Treatment of Municipal Wastewaters". EPA/625/R/010, 
Sept. 2000. Nat. Risk Manag. Res. Laboratory, office of R/D, U.S. EPA, Cincinnati, OH: pp 12-33

Kaseval, M. E. (2004), "Performance of a Subsurface Flow Constructed Wetland in Polishing Per-Treated Wastewater - a Tropical Case Study ", Water Res., Elsevier Publ., Vol. 38, pp.681-687.

MacLaren Engineeres. (1982). "Planners and Scientists Incorporated, Thorne, Stevenson and Kellogg, Atkins Land and water management and Egyptian Technical Consulting Office", Vol. 1, prepared for the ARE and UNDP. Rep. EGY/76/001-07: pp 40 - 45

Mitsch, W. J. and Gosselink J.G. (2000), "Wetland", $3^{\text {rd }}$. Ed., John Wiley \&Sons, N. y: pp 1-5

NAWQAM, 1999 Egypt -Canada, "Inception Report, Vol. 4, Drainage Water Reuse and Pilot Schemes", Cairo, Feb. 1999: pp 1-10

(FAO, 1992 and National Academy of Science-National Academy of Engineering, 1973), ECP 501-2005 pp 24-25

National Water Quality and Availability Management NAWQAM comp-3000 (2007). "Operational Drainage Water Reuse Guidelines" Report No: DR-TE-0410-012-FN pp 13-16

Pat Lane (1992), "Egyptian Engineered Wetlands", A Report (Several Volumes) prepared for the UNDP: pp 2-29

TVA, Tennessee Valley Authority (1999), "Conceptual plan: Lake Manzala Engineered Wetland”, UNDP EGY/93/G31: pp 20-25

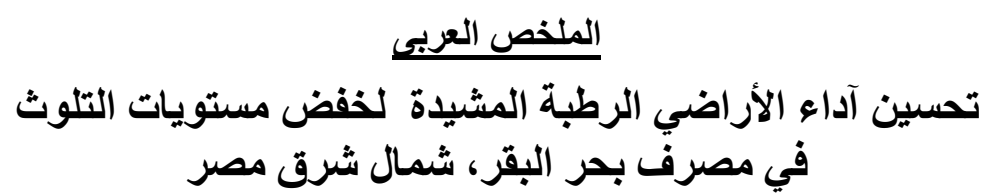

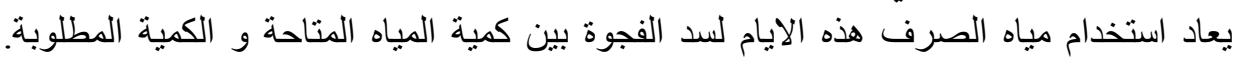

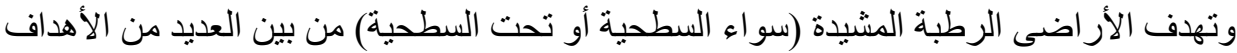

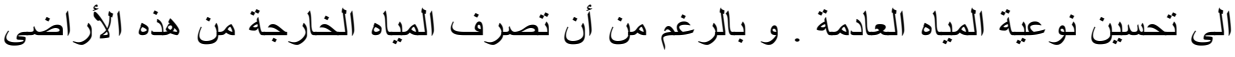

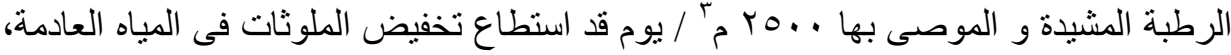

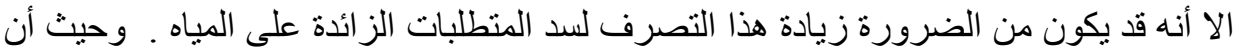

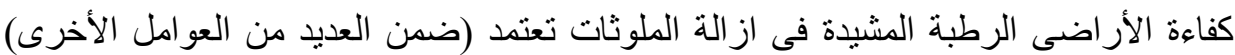




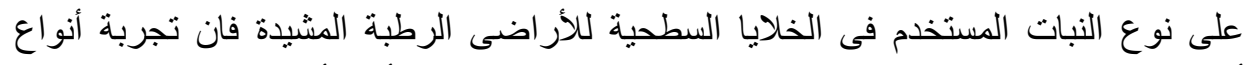
أخرى من النباتات بخلاف نبات البوص المعتاد استخدامه قد يكون أكثر أثرا.

ولذلك أجرى هذا البحث بهدف تقييم أداء الأراضى الرطبة المشيدة سواء سطحية أو تحت

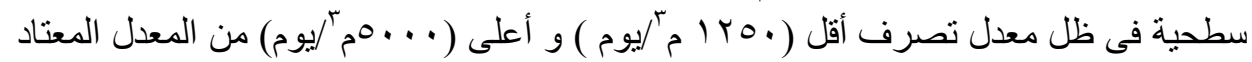

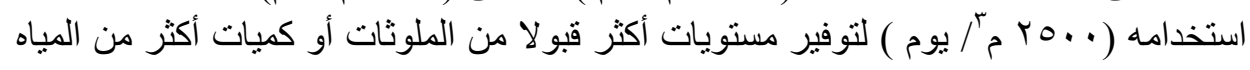

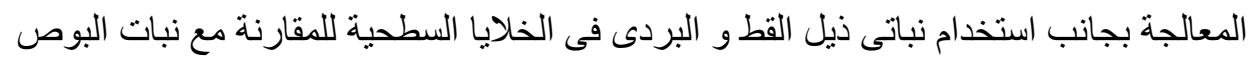

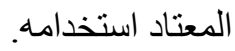
وقد بينت النتائج أن المواد الصلبة العالقة أمكن خفضها الى ألى الدى مستوى لها نتيجة استخدام

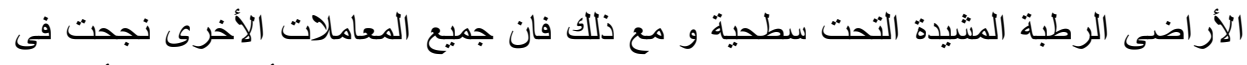

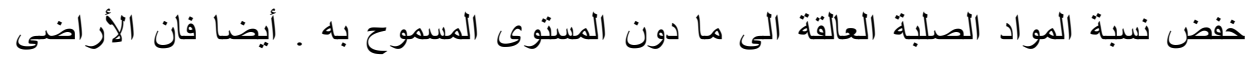

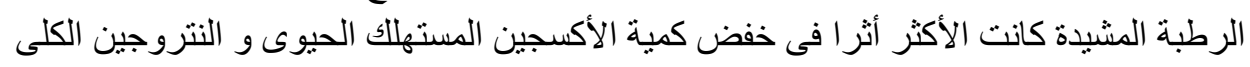

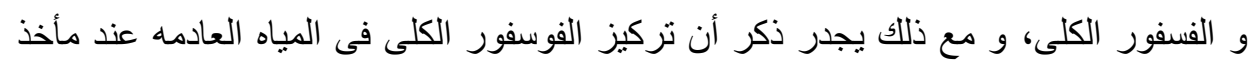

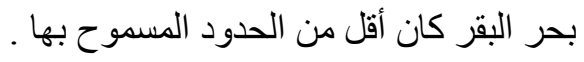

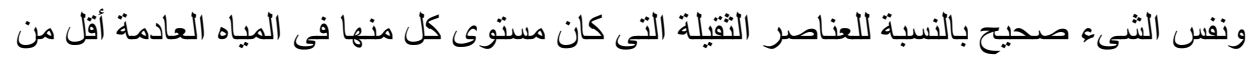

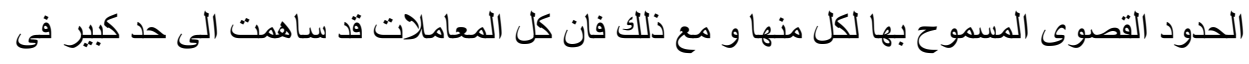

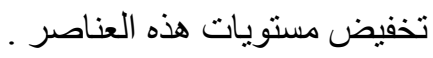

أوضحت النتائج أيضا أنه بغض النظر عن نوع الأرضى الرطبة المثيدة أو نوع النبات

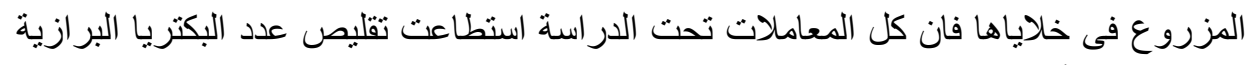

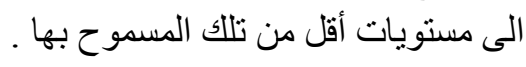

وفى النهاية يمكن استتناج أن أستخدام أى من التصرفات فى الأراضى الرطبة المشيدة يعتمد المداه

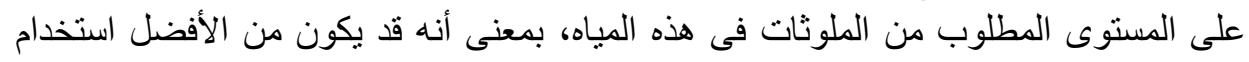

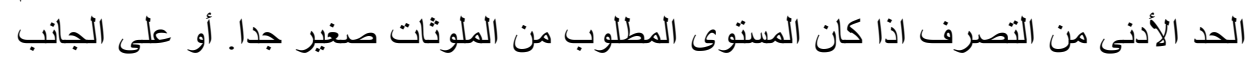

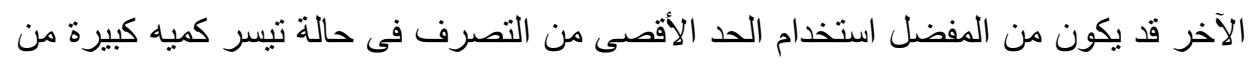

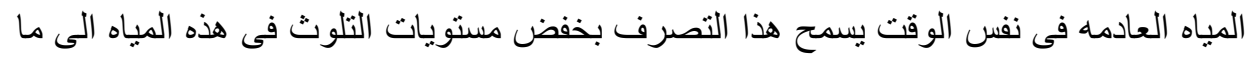
دون الحدود القصوى المسموح بها وفيما يخص نباتات الخدان الخدايا السطحية فقد أمكن أثبات أفضلية

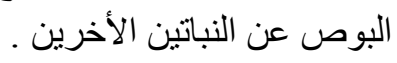

